\title{
香川県における土壌の健康診断に基づく ブロッコリー根こぶ病管理についで
}

\author{
中西充 $*$, 森充 隆 \\ 香川県農業試験場
}

（2017年6月15日受理）

\section{HeSoDiM approach to the control of clubroot in broccoli from Kagawa}

\author{
Mitsuru NAKANISHI and Mitsutaka MoRI \\ The Kagawa Prefecture Agricultural Experiment Station, 1534-1 Kita, Ayagawa-cho Ayauta-gun, Kagawa 761-2306, Japan
}

Keywords: HeSoDiM, clubroot, broccoli.

\section{は じめに}

近年, 香川県のブロッコリーの生産量は増加傾向にある. ここ 5 年間の統計データによると, 直近の平成 27 年産では, 作付面積は 5 年前より約 300 ha 増加して約 1,000 ha, 出荷量 は約 3,000t増加して約 $11,000 \mathrm{t}$ で全国有数の産地となってい る.これは, JAによる定植支援や出荷調整支援など, 支援 の充実, また, 単価の安定によるものと思われる.

このような中, 最近では, 難防除土袞伝染性病害のアブラ ナ科野菜根こぶ病の発生が多く見受けられるようになり，ブ ロッコリーの安定生産に影響を及ぼしている．感染の初期に は，根部にのみ根こぶを生じることから，前年まで地上部に 何ら兆候が発見されなかったほ場でも, 収量が減少するほど 発病する事例が見受けられたり，また，ブロッコリーの根こ ぶ病に対する登録農薬を処理したにもかかわらず防除効果が 十分でなかった事例が報告されており, 各ほ場単位で根こぶ 病の発病をコントロールする必要性が高くなっている.

\footnotetext{
\#第42 回大会シンポジウムを取りまとめた解説.

* ₹ 761-2306 香川県綾歌郡綾川町北1534-1

E-mail: wk6591@pref.kagawa.lg.jp

(C) 日本農薬学会
}

一方, 土壌病害管理の新しい手法として, あらかじめ土壌 診断により, 作付ほ場の発病ポテンシャルを判断し, ポテン シャル別に防除対策を提案する仕組みである「健康診断に基 づく土畩病害管理：ヘソディム（HeSoDiM: Health checkup based soil-borne disease management)」が提案されてお り, 1) 今回, その取り組み事例を紹介する.

なお, 本研究は農林水産省委託プロジェクト研究「気候変 動に対応した循環型食料生産等の確立のための技術開発」の 成果である。

\section{1. 土壤診断項目の抽出}

土壌の生物性や理化学性を事前に調査することにより, ブ ロッコリー根こぶ病のほ場ごとの発病ポテンシャルをあらか じめ評価したうえで, 必要な防除技術を提案する手法を確立 するために, まず, 発病ポテンシャルを評価するための調査 項目の抽出及び選定を行う必要がある. そこで, 県内 29 ほ 場の土銥診断を行い, 発病との関係性を解析した. 香川県の ブロッコリー栽培の作付体系は, 水稲-ブロッコリー作付体 系とブロッコリー連作体系が多いので, 前作が水稲もしくは ブロッコリーである水田転換畑を調査対象とした。 


\section{1. 生物性診断項目}

これまで, 土壌中の根こぶ病菌菌密度の調査方法として, 直接検鏡法 ${ }^{2)}$ で行われてきたが, 検出限界が約 $1 \times 10^{4}$ 個 $/ \mathrm{g}$ であり, 香川県の土壌の多くで, 高い発病度となる可能性が 非常に高く, 発病ポテンシャルを評価する手法としては適さ ない. そこで, リアルタイム PCR法による休眠胞子密度調 查法を検討したところ, $1 \times 10^{3}$ 個 $/ \mathrm{g}$ 以上の定量が可能であ $\eta,{ }^{3}$ 現地ほ場の発病度との関係性も高かった。次に, 簡易 生物検定法 ${ }^{4)}$ を改変したセルトレイ利用生物検定調查によ る発生株率調査を検討したところ, 先と同様, 現地ほ場の発 病度との関係性も高かった。ささらに, 生産者から, 前作の発 病状況や作付した品種, 防除方法等を聞き取った結果から, 発病ポテンシャルを評価する診断方法も有効と考えており, 以上の $3 つ の$ 方法のいずれかを生物性診断項目として選択す ることとした.

\section{2. 理化学性診断項目}

次に, 土㙴理化学性診断項目のうち, 発病度との関連性が 見られたのは, $\mathrm{pH}$, 水中沈定容積, ジチオナイトークエン酸 塩還元溶解鉄 $\left(\mathrm{Fe}_{\mathrm{d}}\right)$ に対する酸性シュウ酸塩可溶鉄 $\left(\mathrm{Fe}_{\mathrm{o}}\right)$ の比率 $\left(\mathrm{Fe}_{\mathrm{o}} / \mathrm{Fe}_{\mathrm{d}}\right.$ 比) であった. ${ }^{5)}$

香川県の主要な土壌である灰色低地土は, 発病しやすい土 壌の一つであり, 発病を抑制するためには, 少なくとも $\mathrm{pH}$ を 7.0 以上に高める必要があるとされ, ${ }^{6)}$ 今回の結果も $\mathrm{pH} 7$ 以上では発病度は 20 未満であった。

水中沈定容積が小さくなると発病度が低くなる傾向があっ た. 水中沈定容積は, 水田土壌から畑土壌への性質変化の程 度を示す指標である畑地化指数の分析項目となっており, ${ }^{7)}$ また, 水中沈定容積が小さくなると, 採土率の上昇や保水力 の低下につながると考元られている。 ${ }^{8)}$ また，一方，排水性 の悪化が, 根こぶ病の発生原因の一つであることが知られて おり, ${ }^{9,10)}$ 畑地化の進行により, 排水性が向上した結果, 発 生が抑制される土壌環境になったと考えられた。

表 1. 土壌診断項目と評価基準

\begin{tabular}{|c|c|c|c|}
\hline 診断項目 & \multicolumn{3}{|c|}{ ポテンシャルしベル評価基準 } \\
\hline $\begin{array}{c}\text { 1. 根こら”病菌 } \\
\text { 休眠胞子密度 } \\
\text { (対数値) }\end{array}$ & $\begin{array}{c}\text { 検出限界以下 } \\
\text { O }\end{array}$ & $\begin{array}{c}\text { 2.5以上4.5未満 } \\
+3\end{array}$ & $\begin{array}{l}4.5 \text { 以上 } \\
+5\end{array}$ \\
\hline $\begin{array}{l}\text { 2.トレイ利用 } \\
\text { 生物検定の発病度 } \\
\text { (DRCパターン) }\end{array}$ & $\begin{array}{c}\text { 発病度=0 } \\
\text { DRC=発生抑止型 } \\
0\end{array}$ & $\begin{array}{c}\text { 発病度1以上50末満 } \\
\text { DRC=抑止性なし } \\
+3\end{array}$ & $\begin{array}{c}\text { 発病度50以上 } \\
+5\end{array}$ \\
\hline $\begin{array}{l}\text { 3. 前年の発病株 } \\
\text { 率亡過去の発生の } \\
\text { 有無 }\end{array}$ & $\begin{array}{c}\text { 発病度=0 かつ } \\
\text { 過去にも発病なし } \\
0\end{array}$ & $\begin{array}{c}\text { 発病度1以上80末満 } \\
+2\end{array}$ & $\begin{array}{c}\text { 発病度80以上 } \\
+3\end{array}$ \\
\hline $\begin{array}{l}\text { 4-1. 問診 } \\
\text { （耐病性品種） }\end{array}$ & $\begin{array}{c}\text { 前年作の品種：耐 } \\
\text { 病性品種利用なし } \\
\mathrm{O}\end{array}$ & $\begin{array}{c}\text { 耐病性品種利用 } \\
+1\end{array}$ & \\
\hline $\begin{array}{l}\text { 4-2. 問診 } \\
\text { (定植時の薬剤処 } \\
\text { 理の有無) }\end{array}$ & $\begin{array}{c}\text { 前年作の定植時 } \\
\text { 処理なし } \\
0\end{array}$ & $\begin{array}{c}\text { 前年作の定植時 } \\
\text { 処理あり } \\
+1\end{array}$ & \\
\hline \multicolumn{4}{|c|}{ 土壤理化学性診断 } \\
\hline 診断項目 & \multicolumn{3}{|c|}{ ポテンシャルしベル評価基準 } \\
\hline 5. $\mathrm{pH}$ & $\begin{array}{c}\text { 7.2以上 } \\
-2\end{array}$ & $\begin{array}{c}\text { 7.2末満 } \\
0\end{array}$ & \\
\hline 6. $\mathrm{Fe} \_\mathrm{o} / \mathrm{Fe} \_\mathrm{d}$ t比 & $\begin{array}{c}\text { 50未満 } \\
-1\end{array}$ & $\begin{array}{c}50 \% \text { 以上 } \\
0\end{array}$ & \\
\hline 7. 水中沈定容積 & $\begin{array}{c}12 \mathrm{ml} / 1 \mathrm{Og} \text { 末満 } \\
-1\end{array}$ & $\begin{array}{c}12 \mathrm{ml} / 10 \mathrm{~g} \text { 以上 } \\
0\end{array}$ & \\
\hline
\end{tabular}


$\mathrm{Fe}_{\mathrm{o}} / \mathrm{Fe}_{\mathrm{d}}$ 比が小さくなると, 発病度が小さくなる傾向に あった，一般的に，水田土袞では，還元・酸化の繰り返しに 伴い，還元鉄量の増加がみられ， $\mathrm{Fe}_{\mathrm{o}} / \mathrm{Fe}_{\mathrm{d}}$ 比が高くなる一方，

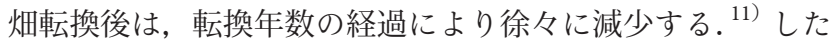
がって， $\mathrm{Fe}_{\mathrm{o}} / \mathrm{Fe}_{\mathrm{d}}$ 比が低いことは，畑地期間が長いことが考 えられ, 先の水中沈定容積と同様, 畑地化により, 根こぶ病 の発生が抑制されたと考えられた。

以上より, 生物性診断項目は, 根こぶ病菌休眠胞子密度も しくはトレイ利用生物検定の発病度，または問診結果を，理 化学性診断項目は, $\mathrm{pH}$, 水中沈定容積, $\mathrm{Fe}_{\mathrm{o}} / \mathrm{Fe}_{\mathrm{d}}$ 比の3 項目 とし，評価基準をそれぞれ設定した（表1).さらに，診断 結果に応じて評価点数を算出し, 各ほ場の発病ポテンシャル レベルを導き出すこととした（表2）。

\section{2. 個別防除技術の評価}

ブロッコリーの根こぶ病の防除対策としては, (1)化学合成 農薬による防除, ${ }^{12)}$ (2)抵抗性品種の導入, ${ }^{13)}$ (3)転炉スラグ施 用による土㙴の酸性改良 ${ }^{14)}$ がある。発病ポテンシャルに応 じた防除技術をメニュー化するにあたり，これら防除技術の 力量を評価することが必要であったことから，それらの評価 を行うとともに，防除技術を実施するに当たっての注意点を 把握した。

\section{1. 調查基準の見直し}

ブロッコリーは根こぶが着生したとしても収量への影響が 少ない品目とされている. ${ }^{13)}$ 収量と関連した発病調査基準と するため, 従来の発病調査基準 ${ }^{2)}$ の見直しを行った，従来 の基準で発病程度 3 となった株について, 出荷に際して充分 な花蕾重とされる $300 \mathrm{~g}$ を超えた株が約 $60 \%$ あり，また，花 蕾重と根数の相関係数 $r$ は 0.597 となり, 有意な相関を認め た．花蕾重 $300 \mathrm{~g}$ 以上を確保できた株の根数は，8本以上の 株が約 $84 \%$ を占めることがわかった。なお， $300 \mathrm{~g}$ 未満の株 では, 8 本未満の株が約 $73 \%$ となった。 以上のことから, 従
来の程度 3 の基準を根数を加えた基準で細分化することによ り，収量に関連した基準となると判断した。 ${ }^{15)}$

\section{2. 定植前土壤処理混和薬剤の処理域の検討}

定植時の根こぶ病菌污染土までの土壌深の違いが発病に与 える影響を検討し，率いては定植時に農薬等で保護すべき 根域を明らかにする目的で試験を実施したところ，ブロッコ リーの夏まき栽培作型において, 定植時に土壤表層 $5 \mathrm{~cm}$ の 根域を根こぶ病菌から保護することで根部の発病度が低く なり，かつ収量減を回避できることが明らかとなった. ${ }^{16)} ま$ た, 表層 $5 \mathrm{~cm}$ の感染回避にフルアジナム粉剂等の土㙵処理 薬剂の定植直前処理後の表層土壌混和が有効であった.

\section{3. 定植前土壤処理混和薬剤の処理時期の検討}

ブロッコリー根こぶ病に登録のあるもののうち，現場でよ く使用されている農薬の有効成分であるフルアジナムおよび フルスルファミドの土壌中の挙動を確認する試験を実施した ところ, 土㙵に添加したフルアジナム及びフルスルファミド が，処理 1 日後の残留量の約半分まで分解するのに要した日 数は, フルアジナムで約 14 日間, フルスルファミドで約 45 日であった. ${ }^{17)}$ また，フルアジナム及びフルスルファミドの 土壌中での下方向の移動について, 表層から $5 \mathrm{~cm}$ 以上移動 したのは, 最大で残留量全体の $4 \%$ 未満であった. ${ }^{17)}$

安定的な効果を得るためには, 土壌処理後の耕耘を丁寧に 行うこと, 処理後速やかに定植を行うことが重要であると判 断した。

\section{4. 定植前土壌処理混和薬剤の処理濃度と根こぶ病菌菌 密度の関係}

根こぶ病菌休眠胞子の接種菌密度別の薬剤防除効果につい てポット試験で検討した結果, 根こぶ病菌の休眠胞子密度が 高まることで, 防除効果を得るのに必要な薬剤濃度は高まる ことが示唆された。その程度は, 各登録薬剂の単位面積当

表2. 発病ポテンシャルレベルと評価点数

\begin{tabular}{|c|c|}
\hline $\begin{array}{l}\text { 発病ポテン } \\
\text { シャルレベル }\end{array}$ & 評価点数総合計値 \\
\hline 1 & $\begin{array}{l}\text { 1, } 2 \text { 単独または3と40組み合わせ合計値と5 } \\
\text { および (6または } 7 \text { ) の合計値がO以下 }\end{array}$ \\
\hline 2 & $\begin{array}{c}\text { 1, } 2 \text { 単独または3と4の組み合わせ合計値と5 } \\
\text { および (6または } 5 \text { 合計値が1 } \\
\text { 【ただし、3の值が2の場合はしべル3とする】 }\end{array}$ \\
\hline 3 & $\begin{array}{c}\text { 1, } 2 \text { 単独または3と4の組み合わせ合計値と5 } \\
\text { および (6または } 5 \text { の合計値が2〜 }\end{array}$ \\
\hline 4 & $\begin{array}{c}1,2 \text { 単独または } \\
\text { および }(6 \text { または組み合わせ合計値と5 } \\
\text { ( } 5 \text { 合計値が5 }\end{array}$ \\
\hline
\end{tabular}


たりの適用使用量を $10 \mathrm{~cm}$ 深で処理した場合の処理濃度の時 に，休眠胞子密度 $1 \times 10^{5}$ 個 $/ \mathrm{g}$ までは有効であるが， $1 \times 10^{6}$ 個／gでは十分な防除効果が得られない場合があった. ${ }^{16)} し$ かし, 各ほ場の休眠胞子密度の調查結果から, 休眠胞子密度 が一方的に上昇することはなく，定植時の休眠胞子密度は多 くの國場で $1 \times 10^{5}$ 個 $/ \mathrm{g}$ 以下にあったことから, 一定の薬 剂濃度を確保することで実用上は問題なく防除効果が得られ ていると考える。ただし，根こぶ病の菌系の病原性により防 除効果が変わる場合もあるので, ${ }^{18)}$ この点については今後防 除効果の安定性について注視する必要はある.

\section{5. 耐病性品種の防除効果評価}

而病性品種「グリーンキャノン」の防除効果並びに本県で の栽培適応性について検討した結果，耐寒性から作期は9月 下旬までに定植する作型に限定されるものの高い発病抑制効 果を認めた。

\section{6. 土䁃改良資材の防除効果評価}

香川県内で広く分布している灰色低地土及び黄色土で転 炉スラグの効果確認試験を実施したところ，2t/10aの施用 量で $\mathrm{pH} 8$ 以上まで酸性矯正可能であり, 定植期から収穫期 まで, pH 7 以上を維持していた。また, 発病度が低下し収 量も確保することが可能であった。一方，水稲との輪作体系 で同様の試験を行ったところ，水稲の品質が低下するとと
もに，施用後水稲を 2 年間作付けすると $\mathrm{pH} 7$ より低下した。 したがって，水稲との輪作体系での施用は控えるべきと考え られた。

また, 土㙵酸性矯正のもう一つの方法として, 灰色低地 土を対象に消石灰施用による効果確認試験を実施した。香 川県の主要な土壤である灰色低地土において, 処理量 400 $500 \mathrm{~kg} / 10 \mathrm{a}$ で, 一定の収量を確保しながら, 根こぶ病の発病 を抑制する傾向が得られた。しかし，ブロッコリー中の微量 要素含有率が低下する傾向が認められ, 栽培ほ場への適応を 考慮した場合には, 微量要素欠乏が発生する可能性があると 思われた. ${ }^{19)}$

以上の個別防除技術を発病ポテンシャルレベルごとにとり まとめた（表3）.

\section{HeSoDiM の導入に向けて}

以上の結果をもとに，ブロッコリー根こぶ病のヘソディム マニュアルを作成した. ${ }^{20)}$ 本マニュアルをもとに，一部産地 で，ほ場ごとにカルテを作成して，発病ポテンシャルを総合 評価し，防除メニューを提案している．HeSoDiMに興味の ある生産者も居るが，防除技術の提案に対してのみ関心が 高いケースが多く, 依然として過剩防除となる場合も見ら れる. 今後, 診断結果をフィードバックして，マニュアルを 高度化するとともに, HeSoDiMの考え方を生産者に理解し てもらうこと, また, 分析調査および診断を担う機関の育成

表3. 発病ポテンシャルレベルと個別防除技術

\begin{tabular}{|c|c|}
\hline しベル & しベル別防除技術 \\
\hline 1 & 無防除 \\
\hline 2 & $\begin{array}{l}\text { (1)定植前育苗セルトレイ薬剤灌注 } \\
\text { (2)土堙pHを転炉スラグまたは消石灰で8.O以上に矯正（ただし、 } \\
\text { 水田との輪作圃場を除く） }\end{array}$ \\
\hline 3 & $\begin{array}{l}\text { (1)定植前土壌混和処理薬剤または定植直後灌注薬剤 } \\
\text { (2)土堙pHを転炉スラグまたは消石灰で8.O以上に矯正（ただし、 } \\
\text { 水田との輪作圃場を除く） } \\
\text { (3)耐病性品種の利用 } \\
\text { (4)作期の移動（10月中旬以降の定植） } \\
\text { 【(3)、(4)は(1)と併用 } 3 \text { (3)、(4)の併用は品種特性から不可】 }\end{array}$ \\
\hline 4 & 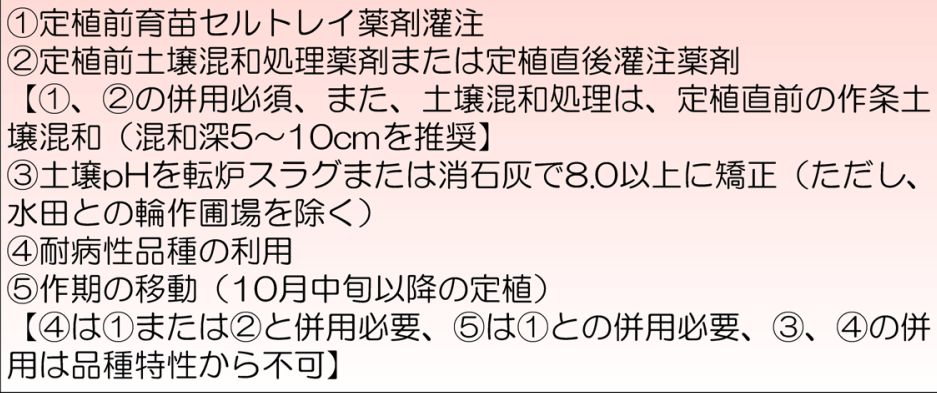 \\
\hline
\end{tabular}


が，重要になってくると思われる．

\section{引 用 文 献}

1) S. Tsushima and S. Yoshida: 2012 FFTC-TUA International Seminar on Emerging Infectious Diseases of Food Crops in Asia, Abstract 204 (2012).

2）村上弘治：アブラナ科野菜根こぶ病総合防除マニュアル, 東北農 業研究センター, pp. 1-38, 2003.

3) 森 充隆, 中西 充: 日植病報 82, 237 (2016).

4) 吉本 均, 前田和也：和歌山県農水技術七研報 2, 143-148 (2001).

5）中西 充，森 充隆：土肥誌 87, 458-461 (2016).

6）村上圭一, 篠田英史, 中村文子, 後藤逸男：土肥誌 75, 339-345 (2004).

7）土壌環境分析法編集委員会編：土猿環境分析法, 1997.

8）長野間宏, 諸遊英行：農業研究センター研究成果集報 1, 46-53 (1983).

9) H. A. Hamilton and R. Crête: Can. J. Plant Sci. 58, 45-53 (1978).

10) H. Iwama, S. Osozawa, T. Ushiroda and T. Kubota: Soil Sci. Plant Nutr. 40, 293-299 (1994).

11）古川秀顕: 水田土袞とリン酸一供給力と施肥一, 博友社, pp. 5-58, 1984.

12）清水寛二 : 関西病虫研報 29, 45 (1987).

13）池上八郎：岐阜大農研報 38, 11-28 (1975).

14）村上圭一, 篠田英史, 丸田里江, 後藤逸男 : 土肥誌 75, 53-58 (2004).
15）森 充隆, 中西 充, 島田敦之, 中美陽子, 吉田周作 : 気候変動 に対応した循環型食料生産等の確立のためのプロジェクトー土 㙴病害虫診断技術等の開発一農林水産技術会議事務局研究成果 537, 55-63 (2015).

16）森 充隆, 中西 充, 中美陽子, 島田敦之, 對馬誠也：日植病報 79, 226 (2013).

17）中西 充：香川農試研報 63, 27-36 (2013).

18）田中秀平, 吉原茂昭, 伊藤真一, 亀谷満朗：日植病報 63, 183187 (1997).

19）中西 充，森 充隆：土と微生物 71, 13-17 (2017)

20) http://www.pref.kagawa.lg.jp/noshi/seika/sonota/160711.pdf （2017年6月 15 日閲覧）

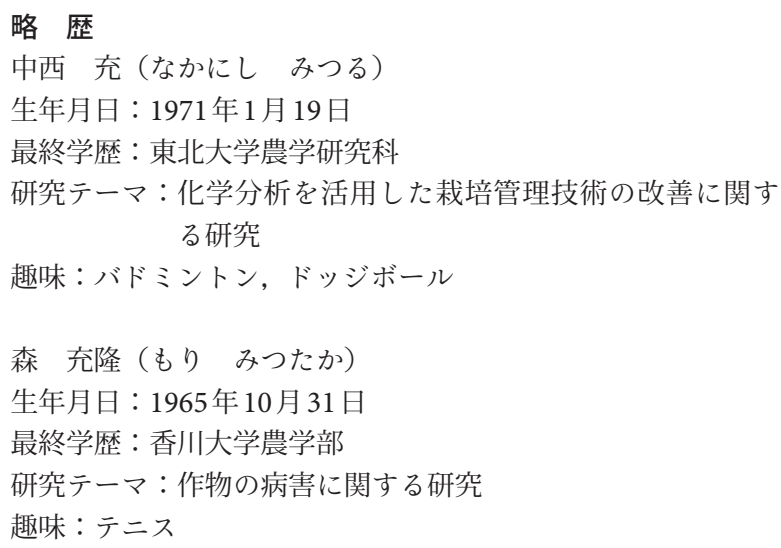

